\title{
SUCCESSES AND CHALLENGES OF COMMUNITY-BASED FARMING AND THEIR INTERRELATIONSHIP WITH SIGNIFICANT CHANGES IN FARM FAMILIES AND RURAL COMMUNITIES
}

\author{
Isamu Ito*, Yukitaka Tanaka
}

School of Global and Community Studies, University of Fukui, Japan.

* Corresponding author e-mail: i-ito@u-fukui.ac.jp

Citation: Ito, I., Tanaka, Y. 2020. Successes and Challenges of Community-Based Farming and Their Interrelationship with Significant Changes in Farm Families and Rural Communities, $J$. Asian Rur. Stud. 4(2): 188-201

\begin{abstract}
Japan has seen a significant development in community-based farming (CBF), particularly in part-time rice farming areas. CBF is a farming system that is performed by a cooperative organization composed of farm households within a traditional rural community aiming to secure efficient and economical management by pooling all the resources. How and why could CBF have developed remarkably? What kind of successes and difficulties has CBF accomplished and faced? How do they interrelate with the changes in farm families and rural communities? To these questions, we offer plausible responses on the basis of our case study in Fukui prefecture. Our study shows that CBF has succeeded in reducing the financial difficulties and labor shortage in participant family farms, as well as sustaining the farmland and the milieu of the community as a whole. However, ironically, the successes have led to a weakening of individual family farms and to promote their dependence on CBF. And then, it has led to the fears about the long-term viability of $\mathrm{CBF}$ itself with generational change. At the beginning, $\mathrm{CBF}$ was a solution supposing the conventional ways of farm family and community. But its implementation accelerated the changes in such conventional ways and produced the need for rebuilding the original system of management and recruitment.
\end{abstract}

Keywords: Agriculture; Community-Based Farming; Part-Time Family Farming; Rural; Sustainable

\section{Introduction}

Japan has seen a significant development in community-based farming (CBF) or "Shuraku Eino" in Japanese. CBF is a type of farming system that is performed by a cooperative organization composed of farm households within a single rural community (or several communities). In CBF, these farm households cooperate to secure efficient, stable, and economical farm management by pooling their farmland, labor force, and other resources.

The idea of CBF has been advocated and practiced in various ways since the 1970s. However, it was not until the concept was clearly described in the new Basic Law of Agriculture in 1999 that CBF attracted the attention of farmers nationwide. Since 2005, which is the year when the government began providing large subsidies to smaller-scale farms that participate in $\mathrm{CBF}$ and to larger-scale individually managed farms, many smaller-scale part-time family farms became motivated to adopt $\mathrm{CBF}$ as an effective measure to cope with crises in their individual agricultural management due to the 
continuous and massive decrease in the price of rice since the 1990s. At the same time, farmers viewed $\mathrm{CBF}$ as a hopeful measure that could sustain each household and the milieu of the conventional rural community by integrating core farmers within the community and securing their ancestral land. As a result, a rapid spread of CBF occurred in the late 2000s. Table 1 shows that the total number of CBF organizations increased by $50 \%$ from 2005 . In particular, the number of corporative organizations that have an advantage in receiving various subsidies has increased rapidly.

Table 1. Change in the Number of CBF Organizations: Nationwide (2005-2018)

\begin{tabular}{lrrrr}
\hline & $\mathbf{2 0 0 5}$ & $\mathbf{2 0 1 0}$ & $\mathbf{2 0 1 5}$ & $\mathbf{2 0 1 8}$ \\
\hline A: Total Number of CBF Organizations & 10,063 & 13,577 & 14,853 & 15,111 \\
B: Number of Corporative CBF Organizations & 646 & 2,038 & 3,622 & 5,106 \\
C: B/A & $6.4 \%$ & $15.0 \%$ & $24.4 \%$ & $33.8 \%$ \\
\hline
\end{tabular}

Sources: Survey Research on CBF by the Ministry of Agriculture, Forestry and Fisheries (MAFF)

However, CBF is not yet widespread throughout Japan. CBF currently covers only $14 \%$ of all cultivated land, including $24 \%$ of farm households and $11 \%$ of rural communities (Table 2). By contrast, CBF has spread widely in part-time rice farming areas, such as in Fukui Prefecture, which is the subject of our investigation. Fukui Prefecture is one of the most typical part-time farming areas with a focus on rice farming. Echizen City, where we conducted a case study on CBF organizations and their base communities, is a representative region of Fukui. CBF covers almost half of cultivated farmland in Fukui, including $70 \%$ of farm households and $51 \%$ of agricultural communities. The same tendency can be found in Echizen City.

Table 2. The Present Spread of CBF in Cultivated Land under Management, Participant Farm Households, and Rural Communities: Nationwide, Fukui Prefecture, and Echizen City

\begin{tabular}{lrrr}
\hline & Nationwide & $\begin{array}{c}\text { Fukui } \\
\text { Prefecture }\end{array}$ & $\begin{array}{c}\text { Echizen } \\
\text { City }\end{array}$ \\
\hline A: Total Number of CBF Organizations & 15,111 & 585 & 54 \\
B: Number of Corporative CBF Organizations & 5,106 & 232 & 17 \\
C: B/A (\%) & $33.8 \%$ & $39.7 \%$ & $31.5 \%$ \\
D: Cultivated Land Area under CBF Management (hectares) & 481,812 & 14,937 & 1,121 \\
E: Total Cultivated Land Area under Management (hectares) & $3,451,444$ & 35,603 & 3,396 \\
F: D/E \% & $14.0 \%$ & $42.0 \%$ & $33.0 \%$ \\
G: Number of Participant Farm Households in CBF & 510,680 & 15,868 & 1,378 \\
H: Total Number of Farm Households & $2,155,082$ & 22,872 & 2,549 \\
I: G/H \% & $23.7 \%$ & $69.4 \%$ & $54.1 \%$ \\
J: Number of Participant Rural Communities in CBF & 30,708 & 940 & 69 \\
K: Total Number of Rural Communities & 138,256 & 1,819 & 175 \\
L: J/K \% & $22.2 \%$ & $51.7 \%$ & $39.4 \%$ \\
\hline Sources: Agro
\end{tabular}

Sources: Agriculture and Forestry Census 2015, Survey Research on CBF in 2017 and 2018 (MAFF)

This study asks the following questions, which were drawn from previous relevant studies (Takeyasu 2011; Kusumoto 2010, 2016; Seki and Matsunaga 2012; Hosoya 2012; Takahashi 2013, 2016; Kitagawa 2014): (1) How and why did CBF develop in 
this area? (2) What were the objective and subjective conditions of the development of CBF? (3) What kind of success have CBF organizations accomplished? (4) What kind of difficulties have CBF organizations faced? (5) Do the successes and difficulties have any interrelationship with the changes in farm families and/or rural communities?

On the basis of field research and the collection of relevant statistics, we obtained significant information concerning the first four questions and have arrived at plausible responses. We provide the outlines of our responses for the first four questions in Sections 3 and 4 and answer the fifth question in Section 5. The final goal of our study is to identify the changes in Japan's farm families and rural society that are supposed to be implied in the development of $\mathrm{CBF}$ and to discern whether these changes are fundamental. If the changes are fundamental, how will Japan's farm families and rural society be transformed? We believe that this question is the most important question for rural sociology. In Section 5 and 6, we will discuss our research findings related to this question.

\section{Research Methods}

We adopt the monographic case-study approach to the above research questions because it is fit for exploring the "how and why" of the genesis and developments of social phenomena (see Ito, 2012). We have selected two villages in Echizen City as the subjects of our case study because they have all the characteristics of rural communities in part-time rice farming areas, at the same time, they have some distinctiveness that makes it possible for us to discern the important factors for the developments and the difficulties of CBF (see Section 4-1).

Since 2012, we have conducted the individual and group interviews with the core members of CBF organizations regularly to obtain the information on the developments of CBF as well as the members' views on farming, family, and rural life. We also have made several participant observations in the village meetings and festivals to obtain the first-hand information on the actual conditions of the residents' lives and their value system. Descriptions of Section 4 and 5 are given on the basis of these information.

In our study, we utilize the various kinds of the national statistics including National Census, Agricultural and Forestry Census, Survey Research on CBF, Industrial Statistics, and Basic Residents' Registry to confirm the typicality and characteristics of our cases comparing with the nationwide trends and distributions (see Section 1 and 3). Most of them are available on the web site of $e$-Stat (Portal Site of Official Statistics of Japan). We also utilize the official statistics and administrative documents provided from the departments of agricultural administration of Echizen City and Fukui Prefecture to check and supplement our own research data.

\section{Conditions for the Spread of CBF in Part-Time Rice Farming Areas 3.1 Local Industries, Dependence on Off-Farm Jobs, and Labor-Saving Rice Farming}

Why did CBF spread widely in part-time rice farming areas? First, as the most important economic condition, we can answer this question by pointing to the thickness of local industries and the heavy dependence of farm households on off-farm incomes for their family finances.

According to the 2015 Agriculture and Forestry Census, part-time farm households whose main income was earned from off-farm jobs account for $75.7 \%$ and $77.2 \%$ of the 
total number of commercial farm households in Fukui Prefecture and Echizen City, respectively; by contrast, these households account for 54.3\% nationally. The 2016 Statistical Surveys on Agricultural Management shows that part-time farm households in Fukui earned 2,481,000 yen from off-farm jobs (49.5\% of total income), 2,135,000 yen from pensions $(42.6 \%)$, and only 401,000 yen from farming $(8.0 \%)$, whereas the national averages were 1,403,000 yen from off-farm jobs $(26.9 \%), 1,952,000$ yen from pensions $(37.5 \%)$, and $1,851,000$ yen from farming (35.6\%). By taking into account that recent research on farm family finances by MAFF did not calculate the incomes of household members who are not involved in agricultural management, it is estimated that the actual income from off-farm jobs is significantly higher than that in the reports.

In Fukui, various types of local industries have long provided farm families with rich opportunities for off-farm employment. These industries include traditional craftwork; textile industries; chemical production; manufacturing of machine tools, eyeglass frames, or electrical equipment; and tertiary industries such as commerce, service, and finance industries. Manufacturing industries employ the largest percentage of the working population: $21.7 \%$ in Fukui and 34.2\% in Echizen City. By contrast, agriculture employs only $3.5 \%$ and $2.6 \%$ of the working population in Fukui and Echizen City, respectively (2015 National Census). 4,742 persons are engaged in family farming in Echizen City on any given day, and their average age was 58.8 years old. Only 1,407 persons are engaged mainly in farming their own land. This number is smaller than that of commercial farm households $(1,773)$. The average age of persons that are mainly engaged in farming is 71.6 years old (2015 Agriculture and Forestry Census).

These statistics and our earlier observations (Ito, 1996) suggest that farm households in Fukui have long adopted a strategy to leave their family farms to elderly members and apply most of their labor to off-farm work to secure and increase their finances. Most family members engage in off-farm jobs in the form of full-time employment, such as office work, factory work, and public service. These workers can assist in family farming in their spare time but usually concentrate their attention to their regular jobs. To realize this combination of full-time off-farm employment and farming, the type of farming system used must be both laborsaving and profitable to some degree (e.g., single-rice farming).

\subsection{Concentration on Rice Farming and Worsening of Agricultural Business}

Farming in Fukui is characterized by a focus on rice farming. The total farmlands of Fukui Prefecture and Echizen City comprise 90.8\% and 95.1\% paddy fields, respectively (the national average is $54.4 \%$ ). These rates are the highest rates in Japan (2016 Statistical Survey on Cultivated Land). Rice farming produces $61.3 \%$ of the total agricultural output of Fukui (47 billion yen) and $67.0 \%$ of the total output of Echizen City (4.17 billion yen); the national average is $18.0 \%$ (2016 Survey on Agricultural Income). According to the 2015 Agriculture and Forestry Census, $81.8 \%$ and $91.6 \%$ of the farms in Fukui and Echizen are classified as "single-rice farms," respectively.

Highly efficient machines and agricultural chemicals ${ }^{2}$ have been utilized in most paddy fields since the 1980s (Ito, 1996). On average, each farm cultivates 2.22 hectares of land in Fukui and 1.84 in Echizen (the national average is 2.20 hectares) (2015 Agriculture and Forestry Census). These sizes are twice those in 2005 because of the rapid spread of $\mathrm{CBF}$ organizations and the growth of individual larger-scale farms in 
this decade. However, each family farm cultivates only 1.51 hectares in Fukui and 1.30 in Echizen on average (the national average is 2.19 hectares). Economically, these farms must indeed be too small in size and are overinvested in machines, but this type of farming has been a reasonable choice for each household to make a living that is consistent with family farming traditions on ancestral farmland.

However, the massive decrease in rice prices and the tightening of the rice acreagereduction policy that arose with the trade liberalization of agricultural products in the 1990 s seriously damaged the agricultural businesses of family farms. Rice prices decreased by over $30 \%$ between the $1990 \mathrm{~s}$ and the $2000 \mathrm{~s}$, and the reduced rice areas expanded to one million hectares in the $2000 \mathrm{~s}$, which account for almost $40 \%$ of the total paddy fields in Japan. A significant decrease in the profitability of farming has forced family farms in Fukui to reconsider their conventional family farming and livelihood strategies. During this time, farm households became aware of CBF.

\subsection{Acquiring Core CBF Members in an Aged Society}

The most important condition for CBF in human resources would be the manner in which to include core members who can take charge of the main farm work and/or management. The main reason for the failure to establish CBF organizations is the absence of this condition. As a typical part-time farming area, Fukui has a great advantage in finding core members among males who have retired from off-farm jobs at the age of about 60 years old. Given that they could work from home and support their home farming in their spare time, these men have already made some preparations for farming in their home village. At the same time, because they are well accustomed to business or administrative work, they could contribute to establishing and maintaining $\mathrm{CBF}$ as a corporative organization. Moreover, given that they have been educated by their parents' generation to be familiar with the conventions, practices, and sense of values of a traditional farm family and community life, they will be able to sustain their farm households and the milieu of the conventional rural community.

Our case study confirms the existence of a cohort of male household members who have the abovementioned abilities or dispositions and who can play a key role in establishing and maintaining CBF. They belong to the generation born between the early 1940s and the early 1950s, including the "postwar baby boomers." They account for the biggest percentage in all male generations in Echizen City $(14.0 \%)$ and in our case villages $(14.8 \% \text { and } 19.2 \%)^{3}$. In our case villages, all core members belonged to this cohort from the start.

\section{Successes and Challenges in CBF: Echizen City Case Study 4.1 Typicality and Distinctiveness of the Case Villages}

In this section, we describe the successes that $\mathrm{CBF}$ has gained and the challenges that CBF now faces on the basis of our case study of two villages: $S$ village and $M$ village. Let us begin with the typicality and distinctiveness of the cases. Both $S$ village and $M$ village have all the characteristics of rural communities in the part-time rice farming areas of Fukui with regard to farming method, farmland, population and household compositions, and neighborhood associations (see Box 1 and Box 2 for further details). Therefore, we can say that both are typical villages in Fukui. 


\begin{tabular}{|c|c|c|}
\hline \multicolumn{3}{|c|}{ Box 1. S Village Characteristics } \\
\hline Population & $\begin{array}{l}\text { Actual residents in 2018: } 57 \\
\qquad \text { (54 natives, } 3 \text { newcomers })\end{array}$ & $\begin{array}{l}\text { Residents in 1995: 119* (119 natives) } \\
\text { Households in 1995: } 23 * \text { (23 natives) }\end{array}$ \\
\hline \multirow{2}{*}{ Composition: } & \multicolumn{2}{|c|}{ Working population: 31 (9 farming, 22 off-farm jobs) } \\
\hline & Elderly Population (over 65): 35 (61.4\%) & Junior Population (under 15): 4 (7.2\%) \\
\hline Households & Total Number: 22 (19 natives, 3 newcomers) & Average Number of Household Members: 2.6 \\
\hline Composition: & $\left\{\begin{array}{l}\text { Farm Households: } 9 \\
\text { Landholding Nonfarm Households: } 9 \\
\text { Nonfarm Households: } 5 \text { (3 newcomers) }\end{array}\right.$ & $\left\{\begin{array}{l}\text { One-Person Households: } 6 \\
\quad \text { (3newcomers) } \\
\text { Elderly Couple Households: } 8 \\
\text { Two-Generation Households: } 3 \\
\text { Three-Generation Households: } 5\end{array}\right.$ \\
\hline Farm Land & $\begin{array}{l}\text { Cultivated Land under Management: } 20.2 \\
\text { hectares }\end{array}$ & Paddy Field: 20 hectares \\
\hline & & Upland Field: 0.2 hectares \\
\hline $\begin{array}{l}\text { Neighborhood } \\
\text { Association }\end{array}$ & Member Households: 22 & Neighborhood Groups: 3 \\
\hline Activities: & \multicolumn{2}{|c|}{$\begin{array}{l}\text { Mutual help in funerals, weddings, and other ceremonial occasions. Cleaning irrigation channels. } \\
\text { BBQ parties and Soba parties. A traditional spring water festival. Maintenance of a village } \\
\text { shrine. Communications with city hall. }\end{array}$} \\
\hline
\end{tabular}

\begin{tabular}{|c|c|c|}
\hline Population & $\begin{array}{l}\text { Actual residents in 2018: } 145 \\
\text { (108 natives, } 37 \text { newcomers) }\end{array}$ & $\begin{array}{l}\text { Residents in 1995: } 106^{*}(106 \text { natives }) \\
\text { Households in 1995: } 27^{*}(27 \text { natives })\end{array}$ \\
\hline \multirow{2}{*}{ Composition: } & \multicolumn{2}{|c|}{ Working population: $46-53^{* *}$ ( 9 farming, $37-44$ off-farm jobs**) } \\
\hline & Elderly population (over 65 ): $31 * * *$ & Junior population (under 15): 19*** \\
\hline Households & $\begin{array}{l}\text { Total Number: } 33 \\
\text { (23 natives, } 10 \text { newcomers) }\end{array}$ & Average of Household Members: 4.4 \\
\hline Composition: & $\left\{\begin{array}{l}\text { Farm Households: } 11 \\
\text { Landholding Nonfarm Households: } 8 \\
\text { Nonfarm Households: } 14 \\
\quad(10 \text { newcomers })\end{array}\right.$ & $\left\{\begin{array}{c}\text { One-Person Households: } 3 \text { ( } 2 \text { newcomers }) \\
\text { Elderly Couple Households: } 2 \\
\text { ( } 1 \text { newcomer }) \\
\text { Two-Generation Households: } 13 \\
\text { ( } 6 \text { newcomers }) \\
\text { Three-Generation Household: } 15 \\
\quad(1 \text { newcomer })\end{array}\right.$ \\
\hline \multirow[t]{2}{*}{ Farm Land } & $\begin{array}{l}\text { Cultivated Land under Management: } 22.7 \\
\text { hectares }\end{array}$ & Paddy Fields: 22.3 hectares \\
\hline & & Upland Fields: 0.4 hectares \\
\hline $\begin{array}{l}\text { Neighborhood } \\
\text { Association }\end{array}$ & Member Households: 33 & Neighborhood Groups: 3 \\
\hline Activities: & \multicolumn{2}{|c|}{$\begin{array}{l}\text { Mutual help in funerals, weddings, and other ceremonial occasions. Cleaning an irrigation pond. } \\
\text { Holding a traditional fire festival. Maintenance of a village shrine. Communications with city } \\
\text { hall. }\end{array}$} \\
\hline \multicolumn{3}{|c|}{$\begin{array}{l}\text { Sources: *1995 National Census. } * * \text { Estimated number (the working population of nonfarm households could not be } \\
\text { confirmed.) } * * * 2015 \text { National Census. The rest was obtained via informant interviews. }\end{array}$} \\
\hline
\end{tabular}


With regard to distinctiveness, we point to the following characteristics: First, both villages have been blessed with active leaders who could establish cooperative organizations that are associated with $\mathrm{CBF}$ to sustain each household and the conventional milieu of the traditional community. Second, although CBF organizations stay within the base community in most cases (78.5\% in Fukui and $74.1 \%$ nationwide), both villages have developed organizations beyond the boundaries of their single community to secure efficient, stable, and economical farm management. Both have gone beyond the boundaries of their communities because they are located in hilly areas and have some disadvantages in terms of the conditions of agricultural production, namely, in the size of farmland and its operational efficiency.

Nonetheless, there are some important differences between $S$ village and $M$ village. First, although both villages are within commuting distance of Echizen City and other neighboring cities, $S$ village is $10 \mathrm{~km}$ farther away from urban areas than $M$ village. Second, although this distance seems to make the depopulation of $S$ village very serious, the population of $M$ village remains at almost the same level (except with the increase in the newcomer population into developed housing lots). Third, although the CBF organization of $M$ village acquired legal status as an Agricultural Producers' Cooperative Corporation in 2015, $S$ village has not obtained this status yet but is seeking to obtain it in the near future.

\subsection{Successes}

We found concrete instances of the successes and challenges of CBF in these two villages and analyzed their interrelationship with significant changes in farm families and rural communities. However, because of space limitations, we provide only the outlines of our findings in this paper. The essential facts on the CBF organizations of $S$ village and $M$ village are summarized in Box 3 and Box 4.

\begin{tabular}{|c|c|c|c|c|}
\hline \multicolumn{5}{|c|}{ Box 3. $S$ Village CBF Organization: Essential Facts } \\
\hline Year of Operation & \multicolumn{4}{|l|}{2007} \\
\hline Objectives of CBF & $\begin{array}{l}\text { 1. To preserve each } \\
\text { household's farmland } \\
\text { and the community's } \\
\text { entire farmland }\end{array}$ & $\begin{array}{l}\text { 2. To avoid } \\
\text { overinvestment in } \\
\text { farm machinery }\end{array}$ & $\begin{array}{l}\text { 3. To preserve } \\
\text { traditions and } \\
\text { amenities in } \\
\text { rural society }\end{array}$ & $\begin{array}{l}\text { 4. To operate a } \\
\text { reasonable business } \\
\text { by using unified } \\
\text { accounting }\end{array}$ \\
\hline Organization Type & \multicolumn{4}{|c|}{ Voluntary Farming Association } \\
\hline $\begin{array}{l}\text { Business Scale at } \\
\text { the Early Stage } \\
(2008)\end{array}$ & $\begin{array}{l}\text { Farmland: } 5.7 \text { hectares } \\
\text { Member farm } \\
\text { households: unknown }\end{array}$ & \multicolumn{3}{|c|}{$\begin{array}{l}\text { Crops: Rice } 3.2 \text { hectares, Soba } 2.5 \text { hectares } \\
\text { Core persons for farm work and/or management: } 2 \text { (early } 60 \mathrm{~s} \text { ) }\end{array}$} \\
\hline $\begin{array}{l}\text { Business Scale at } \\
\text { Present (2017) }\end{array}$ & $\begin{array}{l}\text { Farmland: } 14.0 \\
\text { hectares }\end{array}$ & \multicolumn{3}{|c|}{$\begin{array}{l}\text { Crops: Rice } 11.0 \text { hectares, Soba } 1.5 \text { hectares, Greenhouses: } 4 \text {, } \\
\text { Watermelon: } 0.3 \text { hectares }\end{array}$} \\
\hline $\begin{array}{l}\text { Member Farm } \\
\text { Households }\end{array}$ & Total: 18 & S village: 12 & \multicolumn{2}{|c|}{$N$ village: 6 (neighboring village) } \\
\hline Labor Force & \multicolumn{4}{|c|}{$\begin{array}{l}\text { Core persons for farm work and/or management: } 4 \text { (two in their } 60 \text { s and two in their early } \\
70 \text { s) } \\
\text { Part-time assistant workers: } 3-4 \text { (female: } 2-3 \text { ) }\end{array}$} \\
\hline $\begin{array}{l}\text { Main Machines } \\
\text { and Facilities }\end{array}$ & \multicolumn{4}{|c|}{$\begin{array}{l}\text { Tractors: } 3 \\
\text { Rice-planting machine: } 1 \\
\text { Garage for machines and office: } 1\left(147 \mathrm{~m}^{2}\right)\end{array}$} \\
\hline $\begin{array}{l}\text { Finances } \\
(2016)\end{array}$ & \multicolumn{4}{|c|}{$\begin{array}{l}\text { Total income: } 19 \text { million yen (Sales of products: } 14 \text { million, Subsidies: } 2.6 \text { million) } \\
\text { Total expenses: } 19 \text { million yen (Production costs: } 10.3 \text { million; Labor costs: } 3.8 \text { million; } \\
\text { Surplus funds: } 0.8 \text { million) }\end{array}$} \\
\hline
\end{tabular}


With regard to the successes of two CBF organizations over the past 10 years, we point to the following four points: First, both organizations succeeded in achieving their primary objective of preserving each member household's farmland, the community's entire farmland, and the milieu of the traditional rural community, including the pastoral landscape of well-maintained paddy fields and farmhouses. They established these objectives because the decrease in farm households, along with the drastic depopulation of the entire community ( $S$ village), the decrease in the farming labor force in farm households, and the increase in nonfarm newcomers ( $M$ village), has increased the difficulty of maintaining each household's farmland and preserving the milieu of the rural community. After 10 years of practicing $\mathrm{CBF}, 70 \%$ of landowners in $S$ village have participated in $\mathrm{CBF}$, and $78 \%$ of all farmlands are cultivated by CBF. In $M$ village, $74 \%$ of landowners have participated in $\mathrm{CBF}$, and $\mathrm{CBF}$ is used to cultivate $56 \%$ of the entire farmland. The rest of the farmland is being cultivated by individual farm households who can secure at least one person from within their households for farming. In general, the considerable increase in abandoned farmland is dominant in hilly and mountainous areas. Therefore, the success in farmland preservation by both CBFs should be appraised highly.

\begin{tabular}{|c|c|c|c|c|}
\hline \multicolumn{5}{|c|}{ Box 4. $M$ Village CBF Organization: Essential Facts } \\
\hline \multirow{2}{*}{$\begin{array}{l}\text { Year of Operation } \\
\text { Objectives of CBF }\end{array}$} & \multicolumn{4}{|l|}{2008} \\
\hline & $\begin{array}{l}\text { 1. To preserve the } \\
\text { community's entire } \\
\text { farmland and the } \\
\text { milieu of a traditional } \\
\text { community }\end{array}$ & $\begin{array}{l}\text { 2. To advance } \\
\text { the welfare of } \\
\text { farm } \\
\text { households }\end{array}$ & $\begin{array}{l}\text { 3. To improve } \\
\text { efficient and stable } \\
\text { farming by using } \\
\text { machines and } \\
\text { cooperation }\end{array}$ & $\begin{array}{l}\text { 4. To supply safe } \\
\text { agricultural products } \\
\text { to consumers }\end{array}$ \\
\hline Organization Type & \multicolumn{4}{|c|}{ Agricultural Producers' Cooperative Corporation (since 2015) } \\
\hline $\begin{array}{l}\text { Business Scale at } \\
\text { the Early Stage } \\
(2010)\end{array}$ & $\begin{array}{l}\text { Farmland: } 10.2 \\
\text { hectares } \\
\text { Member farm } \\
\text { households: } 15\end{array}$ & \multicolumn{3}{|c|}{$\begin{array}{l}\text { Crops: Rice } 8.5 \text { hectares, Soba } 1.7 \text { hectares } \\
\text { Core persons for farm work and/or management: } 4(60 \mathrm{~s})\end{array}$} \\
\hline $\begin{array}{l}\text { Business Scale at } \\
\text { Present }(2017)\end{array}$ & $\begin{array}{l}\text { Farmland: } 26.2 \\
\text { hectares }\end{array}$ & \multicolumn{3}{|c|}{$\begin{array}{l}\text { Crops: Rice } 18.5 \text { hectares } \\
\text { Barley and Soba } 7.2 \text { hectares } \\
\text { Cabbage: } 0.5 \text { hectares }\end{array}$} \\
\hline $\begin{array}{r}\text { Member Farm } \\
\text { Households }\end{array}$ & Total: 29 & S village: 17 & $\begin{array}{l}\text { Y village: } 3 \\
\text { (neighboring village) }\end{array}$ & $\begin{array}{l}K \text { village: } 9 \\
\text { (neighboring village) }\end{array}$ \\
\hline Labor Force & \multicolumn{4}{|c|}{$\begin{array}{l}\text { Core persons for farm work and/or management: } 6 \text { (one in their } 50 \mathrm{~s} \text {, three in their } 60 \mathrm{~s} \text {, and } \\
\text { two in their early } 70 \mathrm{~s} \text { ) } \\
\text { Part-time assistant workers: } 19 \text { ( } 9 \text { semi core, } 10 \text { holidays only) }\end{array}$} \\
\hline $\begin{array}{r}\text { Main Machines } \\
\text { and Facilities }\end{array}$ & \multicolumn{4}{|c|}{$\begin{array}{l}\text { Tractors: } 4 \\
\text { Rice-planting machines: } 2 \\
\text { Combines: } 2 \\
\text { Dryers: } 5 \\
\text { Garage for machines and office: } 1\end{array}$} \\
\hline Finances & \multicolumn{4}{|c|}{$\begin{array}{l}\text { Total income: } 35.8 \text { million yen (Sales of products: } 18.6 \text { million; Subsidies: } 14.2 \text { million) } \\
\text { Total expenses: } 35.8 \text { million yen (Production costs: } 6.6 \text { million; Labor costs: } 8.28 \text { million; } \\
\text { Business profits: } 2.72 \text { million) }\end{array}$} \\
\hline
\end{tabular}

Second, both CBFs succeeded in improving productivity and profitability via efficient land use and labor utilization. Both CBFs have gathered few (four to six) core farmers from within each village and have engaged in the main work of farming and 
management by using larger-scale machines and facilities. As approved agricultural subsidy recipients, they receive considerable funds from the Ministry of Agriculture and local governments, which account for $13.7 \%$ to $39.7 \%$ of their total income, respectively (given that the $M$ village $\mathrm{CBF}$ has obtained corporate status, it has an advantage in receiving various subsidies) As result, both CBFs could earn surplus funds (0.8-2.72 million yen) or business profits. Compared with the situation where almost every farm household operated in the red before CBF, we can say that great progress has been made. However, we must also add that this profitability has been made possible by a significant reduction in labor costs for core farmers. In fact, each core farmer receives only 0.8 million yen per year, which can only serve as a supplementary income for the core farmers' family finances. Considering that almost all core farmers in both villages engaged in CBF farm work after their retirement from off-farm fulltime jobs at the age of about 60 years old, pensions are their main source of income.

Third, as mentioned in Section 3-3, the most important aspect of human resources is that both CBFs succeeded in securing core farmers to engage in farming and management. Belonging to the same generation born between early 1940s and early $1950 \mathrm{~s}$, these farmers returned to work on their family's farms after retirement from various off-farm jobs, such as private company employee, public official, and Japan Agricultural Cooperative employee. In each case, these men have taken the initiative in the planning and execution of CBF. They could play key roles because they have gained abilities and knowledge in administration, accounting, and paperwork during their careers, and these skills could be utilized in the management of CBF organizations. Moreover, they could do CBF work because they shared a sense of crisis in believing that each farm household could no longer sustain its farming operations and maintenance by itself. They recognized that the persons engaged in farming within each household were aging rapidly, whereas younger family members have left home or have no interest in farming even if they continued to live with their parents after being married.

Fourth, according to our observations, the core CBF members are all earnest in their work and seem to find fulfillment in CBF despite experiencing a sense of crisis. We may say that such fulfillment has made them work hard despite their very low wages, which do not correspond to their great contributions. In connection with this finding, we add that CBF could bring elderly and/or female household members some opportunities for new jobs and cash earnings via the introduction of other crops (in addition to rice) or other rural businesses. In fact, several elderly women in $S$ village have created small but new sources of income with the introduction of greenhouse vegetables. In $M$ village, CBF has just started cabbage cultivation to create new jobs.

\subsection{Facing Challenges}

Both CBF organizations have performed their initial objectives and succeeded in overcoming their existing problems through their leaders' earnest efforts over 10 years. However, they have also faced difficulties that their leaders could not predict accurately.

First, the most serious difficulty lies in fears about the long-term viability of CBF with generational change. Over the past 10 years, both CBF organizations could have recruited several retired persons as core members from within each village. Therefore, both organizations could substitute their oldest members (e.g., late 70s) with new 
members of retirement age (e.g., 60). Moreover, the $M$ village CBF could utilize the increased membership to expand its cultivation size and to establish the organization as a corporation.

However, the leaders in both organizations unanimously told us that when they thought about recruitment for the next 10 or 20 years, they could not envisage how they could acquire successors for their organizations from within the villages involved. At the start-up stage of $\mathrm{CBF}$, they anticipated that they could find retired persons who were willing to participate in $\mathrm{CBF}$ as core members just like themselves from within the base village. They also anticipated that in case they could not find anyone in the base villages, they could find someone in the expanded CBF area, including several neighboring villages. This might have been an overly optimistic view because some significant changes in farm family members have occurred, particularly in younger members, and these changes have caused younger generations to distance themselves from farming and their family's farmland in both their minds and behavior ${ }^{4}$. At present, the younger members of part-time farm families have been brought up to be full-time off-farm workers to support the family's finances (see Ito, 1996). Although parents, including core CBF members, strongly expect their sons (or daughters in cases where there are no sons) to live together with them and to take over their family name, ancestral farmland, and family tomb, they rarely expect their inheritors to engage in farming. According to informant interviews in $M$ village, most children in part-time farming households who are in their 40s or younger, including inheritors, had no serious training in farming. Furthermore, some children do not even know the location of their ancestral farmland ${ }^{5}$. Therefore, it would be very difficult to find future core farmers among these children.

Second, CBF developments have caused a loss of interest and engagement in farming among villagers who entrusted the CBF organization with their farmland because of the lack of (or the aging of) farm labor force within households. For CBF organizations, assistant work by members other than core members, such as the ordinary maintenance of paddy fields or canals, is very helpful and necessary to allow core members to focus on the main farm work and management. Although the participation of many people in $\mathrm{CBF}$ activities has been regarded as the key to the revitalization of rural communities, the reality seems to be far from ideal.

Third, for the improvement of productivity and profitability, both CBF organizations have gone beyond the boundary of a single community to expand the area of cultivated land by involving four (in $S$-CBF) or six (in $M$-CBF) villages. For the time being, there does not seem to be any salient problem concerning the conflict of interest between the $\mathrm{CBF}$ organization and each village or between the villages themselves. However, if a $\mathrm{CBF}$ organization wants to maximize its own interests, the objective of both CBFs to preserve the entire farmland and the milieu of the community may be ignored because cultivating smaller lots of farmland are uneconomical.

Fourth, given that the profitability of CBF depends on low wages for core farmers and various subsidies from central and local governments, CBF operations would become difficult if the large reduction in subsidies were to be enforced. It is very likely that the government will reduce the budget for agricultural subsidies. 


\section{CBF and Changes in Farm Families and Rural Communities}

Next, let us discuss the interrelationship between the development of CBF and the changes in families and communities. Our case study shows that CBF is an earnest attempt by farmers in part-time farming households to preserve their farmland and agriculture in the area by utilizing the unity of the traditional rural community and integrating the labor force left within the community. Judging from the abovementioned successes, we can say that CBF has been the best resolution to the present problems of part-time farming areas (e.g., a significant part of individual farm households cannot sustain their farmland and agriculture and the future abandonment of farmlands). Without the development of CBF organizations and their active leaders, the abandonment of farmlands would have quickly spread to other areas. This also means that current rural communities do not play any important role in agriculture as the same way as previous rural communities, except the cleaning of canals or ponds once or twice per year. On the contrary, in our cases, both communities function as neighborhood associations that provide mutual help to residents for ceremonial occasions, communal religious rites, and so on (see Box 1 and Box 2). Both communities face the future task of reorganizing themselves to incorporate the increasing number of newcomers from urban areas.

CBF organizations in both villages are facing several difficulties for the future, in which we can see both the persistence of a conventional orientation toward family and the occurrence of significant changes in farm families. First, there is a salient tendency among younger members whose households entrust CBFs with their entire farmland to lose interest and stop participating in agriculture and farmland cultivation. This problem appears to have existed during the initiation of $\mathrm{CBF}$ because of the younger family members' upbringing and environment. However, it is also certain that the development of $\mathrm{CBF}$ accelerated this tendency. Although this is generally prevalent among younger generations under 40, it would not be valid in the case of younger sons whose households have continued self-managed farming and from whom older family members receive assistance for farm work.

Second, it also seems to be certain that younger family members still have a conventional orientation toward the family. We observed the long-lasting wish to maintain their family lives within traditional rural communities among the farm families in Fukui. They regard stem family types as desirable and worthwhile: two married couples (parents and their son/daughter and his/her spouse) living together on their ancestral estate and having a common housekeeping account while maintaining good relations with village neighbors (Ito 1996). We can estimate the maintenance of such an orientation among the younger generations to a considerable degree judging from the fact that most of the native villagers in $M$ village live in three-generation stem family type households ${ }^{6}$. Fourteen out of 23 native households $(60.9 \%)$ are classified within this type.

By contrast, in $S$ village, only five households can be classified as a threegeneration family type. What has contributed to this significant difference between the two villages? Based on informant interviews and our own observations, we have come to think that three major factors may affect this difference. The first factor is distance to off-farm workplaces. Both villages are within commuting distance of Echizen City, but the disadvantage of being $10 \mathrm{~km}$ farther than $M$ village seems to influence younger generations to leave $S$ village for urban areas. The second factor is the existence of 
schools wherein their children can learn in an appropriate class size, adjust themselves to a competitive environment, continue their studies to a higher-level of education, and obtain good jobs. Although there is a smaller-sized elementary school and a junior high school near $S$ village, younger parents might have moved to urban areas with their children to seek better schools. The third factor is the convenience of living near amenities such as shopping, hospitals, leisure, and public facilities. Considering that $M$ village is very close to an urban area, access to these conveniences is easier than in $S$ village.

If younger members of farm families are satisfied with all these conditions, it is likely that they will continue to live in their native villages; otherwise, it is unlikely that they will stay in their villages. A promising research question for future research is whether we can explain the general housing behavior of younger members of part-time farming families in terms of these factors.

\section{Conclusion}

In most cases, $\mathrm{CBF}$ was initially attempted as a solution for the financial difficulties and labor shortage in each participant family farm as well as for sustaining the farmland and the milieu of rural community as a whole. Our study shows that CBF organizations can succeed in both the tasks when they can recruit some competent core members who had just retired from off-farm jobs. In fact, both of the our CBF organizations have obtained good results through the efforts of these new senior members for ten years.

However, ironically, the successes have led to a weakening of individual family farms and to accelerate their dependence on CBF. And then, it has led to the fears about the long-term viability of $\mathrm{CBF}$ itself with generational change. Originally, CBF was a solution for the difficulties on the assumption that the conventional ways of farm family and rural community remain functional for the sustainability of regional agriculture. But our study shows that the implementation of CBF accelerated the changes in such conventional ways especially among the younger generation of residents in both of our villages. It means that it has become necessary more and more to rebuild the original system of management and recruitment of CBF. In fact, several new attempts in terms of a non-conventional viewpoint are going to make in our case villages. We would like to follow their developments.

\section{Acknowledgments}

We sincerely express our gratitude to the leaders of $S$ village and $M$ village. Our research would not have been possible without their assistance. This work was supported by JSPS KAKENHI (Grant No. 16K04059).

\section{Notes}

1. Past experiences on village-wide farming cooperation may form the background of the present $\mathrm{CBF}$ format. We do not deal with this matter in this study because we have not yet observed the direct influences of these experiences.

2. Recently, rice farming methods that use less or no agricultural chemicals have spread in Fukui to provide added value to rice crops and meet the needs of urban consumers. 
3. Calculations were based on the 2005 National Census. Shortly after, CBF began to spread rapidly.

4. Even in a part-time farming area such as Fukui, there are many farmers who actively engage in farming in individual family farms or farming corporations and have a clear vision and a positive sense of value for agriculture and rural life (see Ito, 2015). Given that these farmers can play an important role in the sustenance of agriculture and rural society, we should be fully aware of their existence.

5. The following sense of the ancestral farmland is exemplary: An informant told us that his son as an inheritor said to him, "Father, I would be happy to take over this ancestral house for our family life, but I will sell our farmland entirely when you die, because the land has no value as an estate. We only have the obligation to pay taxes on this land."

6. It is necessary to investigate the details and the degrees of such an orientation among the younger people empirically. We have conducted a questionnaire survey for the residents in $S$ village and $M$ village on this matter in 2019 . The findings will be reported in another paper.

\section{References}

Hosoya, T. (2012) Sociology of Japan's Farm Household and Rural Community: Case Studies in Rice Farming Areas of Tohoku District. Ochanomizu-Shobo [in Japanese].

Ito, I. (1996). Persistence and Change in Part-Time Family Farming: The Case of Fukui Prefecture, Japan. Memoirs of the Faculty of Education of University of Fukui. Series 3. Vol.52. pp.1-11.

Ito, I. (2012). Methodological Significance of Case-Study Research in Japanese Rural Studies: Lessons from the Rural Studies in Shounai by Masashi Kanno, Otoyori Tahara, and Takashi Hosoya. Journal of Rural Studies. The Japanese Association for Rural Studies. Vol.18. No.2. pp.44-55 [in Japanese].

Ito, I. (2015). Words and Experiences that Reaffirm the Values of Farming and Rural Life: Findings from Qualitative Interview Research in Fukui Prefecture, Japan. Bulletion of Research and Education Center for Regional Environment of University of Fukui. No.22. pp.91-99.

Kitagawa, T. (2014). Trends in Regional Agriculture and the Pillar in Fukui Prefecture, Research Report of the Project for the Structural Analysis of Agriculture. No.4. Chapter 2. Policy Research Institute, Ministry of Agriculture, Forestry and Fisheries. pp.15-28 [in Japanese].

Kusumoto, M. (2010). Evolving Community-Based Farming. Nobunkyo [in Japanese].

Kusumoto, M. (2016). New Developments of Next-Generation Type of CommunityBased Farming. Agriculture and Economy. Showado. Vol.82. No1.1. pp.58-64 [in Japanese].

Seki, M. and Matsunaga K. (2012). Community-Based Farming. Shin-Hyoron [in Japanese].

Takahashi, A. (2013). Transition and Prospect of Community-Based Farming, Agriculture and Horticulture. Vol. 88. No. 5. pp.551-560 [in Japanese].

Takahashi, A. (2016). Expansion of Areas in the Community-Based Farming Organizations. Agriculture and Economy. Showado. Vol.82. No1.1. pp.59-57 [in Japanese]. 
Takeyasu, H. (2011). Revitalization of Rural Communities and Community-Based Farm Cooperatives. Bulletin of Graduate School of Contemporary Society of Kyoto Women's University. No.5. pp.21-41 [in Japanese]. 